\title{
The (Draft) European Charter of the Commons - Between Opportunities and Challenges
}

\author{
Anna Simonati \\ Faculty of Law, Trento University, Italy \\ anna.simonati@unitn.it
}

\section{ABSTRACT}

The concept of ownership, which (in Italy and similarly in other European systems) is still essentially based on private law rules, is currently not sufficient to ensure the satisfaction of the general interest in an increasingly wide access to scarce resources, in the perspective of equality and fairness on the field. At the same time, strong criticism has been expressed about the frequent phenomenon of privatisation of originally public assets and resources. The threats to the pursuit of the public benefit posed by privatisation may be tackled by constructing a new legal framework, aimed to protect the right of the populations to be involved not only in the use, but also in the management of the commons. An expression of this idea is the draft European Charter of the Commons, which is the result of a collective brain-storming by a group of scholars rather than a source of law. Its non-normative nature has allowed its authors to express particularly 'brave' positions. This article takes the Charter as a starting point to focus on some open issues. The main proposal concerns the possible exploitation of new participatory models for the involvement of communities of users in the strategic decisions on the management of the commons. In such perspective, a brief reference to the Italian legal system is made. In Italy, there are no systemic rules about the commons, but some procedures to involve the interested local communities in the strategic choices have been experimented, which can serve as an illustration also for other EU countries.

Keywords: European Charter of Commons, innovation, participation, public benefit, Italy

\section{Introduction: Methods of the Paper and Expected Results}

This paper is focused on the analysis of the draft European Charter of the Commons, which is a very peculiar document. It is the result of the seminar on The European Charter of the Commons (International University College, Turin, 
2-3 December 2011). ${ }^{1}$ Despite being structured as a statute, the draft is neither an act produced by the institutions operating at the European level, nor a legal source in a national system or an act of soft law. It is just an expression of views by a qualified multi-disciplinary group of scholars, who tried to give a contribution about the broader legal regime of the commons. Its purpose is to serve as a proposal in order to induce legislators and policy-makers on one hand, and the doctrine on the other, to consider the issue of the management of the commons. The text was published without any further comment and no access is allowed to any minutes of the meetings or preliminary acts. Therefore, the articles of the draft are the only starting point for reasoning. Some issues arise therefrom and are particularly interesting in the perspective of administrative law.

As it is well known, such perspective is quite original, because the commons are often studied by economic and sociological scientists, or else in relation to the protection of the environment and natural resources, while in administrative law, research on this topic is more fragmentary. The reason seems to lie, at least partially, in the existence of different opinions about the systemic position of the commons in the conceptual background of public law, especially from the point of view of their legal qualification as private or public (or even intermediate) ownership. This open question raises several doubts. The first one regards, of course, the necessity - or at least the opportunity to lay down a list of commons; this clearly involves the issue of indication of the proper role to be played by national and supra-national legislators and of the possible binding strength of the rules of law in this field. Another open issue arising from some statements contained in the draft Charter regards justiciability. In such perspective, the Charter offers some interesting food for thought, especially in terms of the legitimacy to bring action in defence of the right of the users before a court.

In the paper, some ideas about how the commons may - and perhaps should - be concretely managed, are proposed. A possible solution is found - also in light of the analysed content of the draft European Charter - in the participation by groups of users (primarily, the local populations) in the strategic decisions on the proper management of the scarce resources to be considered as commons. The suggestion is that the basic taxonomic dilemmas about what the commons are should be surpassed, because there is no single, universally applicable answer to this question. The accepted definition of the commons may change depending on the context, but indicating a method to decide what is to be considered a common may be a first, fundamental step toward a full citizenship of the commons in administrative law. In absence of scientific empirical data on the possible value of such approach, the paper briefly describes some preliminary implementations in the Italian legal system of participation, as a method to manage common resources. These tools could be extended to the management of the commons in the strict sense. The comprehensive aim is to offer some keys to understand this complex and compli-

1 Available online at: http://zofijini.net/wp-content/uploads/sites/5/2013/04/skupnost-eu-Rim. pdf. 
cated phenomenon that, in the present as well as in the future, will increasingly involve the concepts and mechanisms of administrative law.

\section{A Fragmented Landscape for Ownership in Europe (Short Remarks)}

The economic crisis has deeply influenced several categories of public law, which are now perceived differently than they used to be. One of the fields where this phenomenon is particularly evident regards the appropriation of goods and the ownership of rights (Glyn, 2007; Leijonhufvud, 2009, p. 741.; Levet, 2012; Gibson, 1993, p. 147; Giddens, 1991).

Especially in Western Europe, the idea of property/ownership is traditionally strong, even though the divergences between the various experiences are deep. In synthesis - and with a certain degree of approximation - one could say that, in the civil law tradition countries, legislators and scholars pay attention primarily to the formal method to acquire, transfer (and possibly lose) the right of property on single goods. In particular, from a theoretical point of view, private and public ownership is still essentially based on private law rules. The latter is conceived, of course, as an exception to the former, but the general coordinates of the legal concepts are the same. In other contexts (the common law tradition countries), however, the main element is how the subjects use the goods, while no particular attention is paid to the formal title of belonging (Bell, 1992, p. 3; Haller, 1998, p. 166; Hopkins (ed.), 2013).

The difference is clear, but, in reality, its practical consequences are not as deep as one could infer. In fact, in many cases the two traditions follow similar paths to reach similar goals, in terms of protection of individual interests and - at the same time - fair distribution of resources among all the parts of the population (Sirgiovanni, 2017, p. 229; della Cananea, 2009, p. 297; Lange, 1981, p. 147; Freedland and Auby, 2006; Samuelson, 2006). Furthermore, independently from the legal historical landscape, it is at present widely recognised that the traditional rules about appropriation are no longer sufficient to ensure the satisfaction of the general interest, which requires an increasingly wide access to scarce resources in the perspective of equality and fairness. In the light of the current crisis, the side of distributive justice has become more and more relevant. From this point of view, the ethical aim at equality has started to produce legal effects, in the sense of a transformation of the sensitiveness for the traditional concepts and categories (Council of Europe, 2011).

\section{The Tragedy of the "Traditional" Tools of Appropriation?}

As it is well known, according to economic scientists (Ostrom, 1988; Ostrom et al., 1994; Ostrom et al., 1999, 278-282; Barnes, 2006), a common is a material or non-material resource, which is 'not exclusive', as it is shared by a community (Leyronas and Bambridge, 2018, p. 11). Clearly, in this economic sense, 
a resource is a common if all the members of a community may (physically) use it. Nonetheless, this (widely shared, but very broad) definition is based on the structural and functional inherent characteristics of certain kinds of assets and resources, while it is not deeply rooted, from an epistemological point of view, in a conceptual and scientific background. Therefore, even though it is concretely used and managed 'in common', a resource may not be recognised as a common on a social or legal ground (Ostrom and Hess, 2007; Stiglitz, 1999; Grazzini, 2011). Actually, the gap between possible efficient common use (or, maybe better, use in common) of some resources and their legal regime is rather frequent. Normally, in fact, goods are either private or public. This means that the rules on appropriation were laid down according to the idea of exclusion of third parties from the strategic decisions about the most fruitful exploitation of such resource.

The efforts to produce a unitary concept of the commons have failed and, at present, there is no decisive (and widely accepted) notion (Hardin, 1968, p. 1243). On the other hand, it is necessary to realise that, for different reasons, it is not possible to create a catalogue thereof serving as a kind of numerus clausus. First, the perception of general interests and needs is quite different among the European populations, depending on both the national economic situation and the inhomogeneous lack or wealth of resources. Second, the existence and typology of public ownership is perceived, from a legal point of view, differently across Europe. Third, also from the perspective of single national legal systems, the introduction of the concept of the commons with a partially "new" physiognomy would request a deep reconsideration of the traditional ownership categories, which are still mostly based on the public/ private dichotomy. It is very difficult to subsume the commons under these concepts, also because they are normally not the subject of individual rights. Therefore, it may be useful changing the point of view: from the kind of ownership to the rules about the management of the commons, possibly with a direct involvement of the communities of users. Consequently, the scientific debate about the commons has been often turned into a speech about the indication of the legal tools that may be used to protect a general right to 'universal resources', the use of which should be granted to everyone (Mishori, 2014, p. 335; Martinez Lopez and Cattaneo, 2014; Camerlengo, 2016, p. 557; Cerulli Irelli, 2016, p. 529; Ciolli, 2016, p. 457; D’Andrea, 2016, p. 433; Staiano, 2016, p. 415; Viola, 2016, p. 381; Caputi Jambrenghi, 2017, p. 1).

In my opinion, none of the 'traditional' legal instruments seems to be, in itself, truly efficient. The conversion of private property into public ownership of entire categories of goods and/or resources, for instance, may not be the best solution, because it is still deeply rooted in the rules of appropriation where the owner is an almost absolute 'master'. An alternative could be the attribution of atypical property rights, either directly to the local communities that are the main users, or to ad hoc non-profit entities with direct and strict links with the same communities (Nussbaum, 2010). Nonetheless, this 
choice is rather complex and requires a potentially deep transformation of the established institutional balances, connected with the transformation of a 'property-based' system into a 'non-strictly-property-based' one. Technically speaking, in fact, the commons are formally not owned by anyone, but their management and use may be useful to all (Pennacchi, 2012; Marell, 2012; Atkinson, 2008). Another possible attempt is to look at the commons not as goods (in a 'classical' sense), but essentially as the subject of expectations (of the communities) and performances (by the public bodies). Hence, the "static" conception of the commons (essentially based on the effort of defining a group of assets and resources to be used in common and some basic rules to be laid down and implemented for this purpose) can be usefully replaced with a more 'dynamic' view. In such 'dynamic' view, the main issue is the method allowing the assets and resources, which - at least partially, on a case-by-case basis - are considered as commons, to be properly managed. All the mentioned topics are well known to the authors of the draft European Charter of the Commons, which represents an effort to properly address this challenge (Ferrarese, 2010; Mattei, 2011; Borch and Kornberger, 2015, p. 1).

\section{Open Issues Arising From the Draft European Charter of the Commons}

\subsection{The (partial) disregard for the legal theoretical background about ownership}

The authors of the Charter decided not to give a close definition of the meaning of the word commons. Besides, the Charter does not include a closed catalogue of the commons. Of course, the reason lies in the different perception of public ownership and the commons as such among the various national legal systems, which makes it almost impossible to find a point of synthesis. Therefore, the concept enshrined in the Charter is very wide and includes the "collective goods or services to which access is necessary for a balanced fulfillment of the fundamental needs of the people". The conceptual ground of the notion is based on the substantial intensity of the population's interest, but has no certain boundaries. Consequently, the aim is to produce "a Europewide catalogue of the commons to be updated regularly because the commons, not being a mere commodity, are a highly dynamic social institution changing in time and space".

This is where one finds all the unavoidable contradictions of an experiment that tries to compound traditional legal tools and new goals. The open problems, in fact, are many and relevant. The authors of the Charter directly give some indications about the typology of the commons to be protected. Here, the double nature of the commons (intended as both goods and utilities) is clear. In fact, according to an expressed rule, "it is necessary that the commons are understood not only as living resources, such as forests, biodiversity, water, glaciers, seabeds, shores, energy, knowledge and cultural goods, 
but also as organized public services, such as schools, healthcare facilities, and transportation". Which, of course, also shows an implicit will not to take into consideration the conceptual aspects related to the appropriation system.

Another contradiction is related to the legal effect of the production of the catalogue, which should be "based on the irreversibility of ecological legal protection, eventually to be granted constitutional status as heritage of Europe in trust for future generations". A logical problem arises from the idea according to which the catalogue must be the starting point of an irreversible legal protection of all its elements. Therefore, it would only be possible to integrate the list with new additions rather than, so to say, by removing some items. This approach, however, does not take into account the inherent scarcity of some resources that could lead to their exhaustion despite a fair and efficient management. Another relevant aspect is the possible scientific and technological progress, which may change the evaluation criteria of the quality of life; in a few years, in fact, what originally was a scarce resource could - in the general perception and, consequently, in legal terms - lose such attribute.

More evidence of uncertainty in managing the traditional legal concepts for new purposes results from a careful study of the concept expressed in the Charter about privatisation in the public sector. A common element throughout Europe can be indicated in the growing importance of this phenomenon over the latest decades (Clarke, 2004, p. 27; Bortolotti and Siniscalco, 2002; Bennett, 1997; Mejstrik et al., 1997; Frydman and Rapaczynski, 1994; Ramanadham, 1993). The authors of the Charter note that the expansion of privatisation and a strong legal favour for corporate power has unduly turned citizens into consumers. This has influenced the perception of common resources and of the (mainly productive) aim of their use. Consequently, privatisation should be allowed only in exceptional cases, when the national legislature, after a deep and careful evaluation, finds that it is strictly necessary.

In my opinion, this is one of the weaknesses - from a conceptual point of view - of the Charter. In fact, besides the explicit reference to a 'traditional' administrative law instrument (privatisation), there is an effort to change its nature according to fairer distributional parameters. It is established that "in the exceptional cases in which privatization may occur, there must be full compensation, recognized and guaranteed ex ante to restore the commons". In this regard, many questions may be asked. It is not clear who is responsible for shelling out compensation, even though the most logical answer seem to be the central authorities in a legal systems, which must take the final decision in each privatisation case. However, nothing is said about the quantification criteria of the amount of compensation. The main open issue, finally, regards the identity of the addressees of compensation. Perhaps, they should be the local populations that are the most direct users of the goods or resources, but their exact identification could be very complicated (and contains at least partial arbitrariness). A possible alternative is to empower the territorial authority, giving it the competence to decide, in light of a participatory sub-pro- 
cedure involving all the stakeholders, how the money should be spent in the public interest.

Finally, the authors of the Charter have indeed kept in mind some other theoretical conceptual elements. In particular, it is made clear that the management of the commons must always be related with "the logic of access and not of exclusion", especially with the aim of granting the widest possible fruitful use to the young and future generations. Although the Charter does not directly address the problem of the possible transformation of property/ownership, it often refers to heritage. This may be relevant because the typical characteristic of heritage is its natural destination to survive and to be transmitted. Therefore, "герroduction and sustainability" must be the main purpose of their use, "no matter if publicly or privately owned".

\subsection{The role of supranational law}

The need for a strong intervention by the legislators at the level of general principles is clear to the authors of the draft European Charter, stating that "a true commonwealth of Europe is possible only by means of constitutional safeguards of the commons through a direct participatory process". This means that the perception of the primary importance of the procedure as a tool for the protection of the commons in the general interest is so strong to require not only its translation into legal terms, but even its codification in hard law at the highest institutional level.

This step calls for both national and supranational legislative efforts. Yet, interestingly, the draft Charter expresses a strong distrust of the traditional supranational dialogue system. The authors assume a somehow political point of view, which is based on a vigorous criticism against the "collusion between the private and public sectors, between State and market actors", which, in practice, is able to preclude "national elected officials to represent the common interests of the people". As it is well known, the lack of democracy has often been indicated as the true weakness of the European institutions, as well (Azman, 2011, p. 242; Follesdal and Hix, 2006, p. 533; Crombez, 2003, p. 101; Eriksen and Fossum, 2002).

As regards the management of the commons, this element could lead to inefficiency in the basic choices. Thus, it could be proposed that an integrated system of rules is developed and implemented at the national constitutional level and at the basic European legislative level. In the national constitutions, there should be an indication of resources and interests, the use of which must be granted to everyone, while the European rules should contain the basic elements for a uniform legal framework about management and involvement of stakeholders and populations.

It can also be noted that, notwithstanding a (at least partially) negative view of European law, the draft Charter contains more than one reference to the 
need for an explicit protection of the commons at the constitutional level of European hard law. The need for a strong legal obligation to ensure a minimum degree of protection of the right of direct access of the populations to the resources is clearly perceived and expressed. Very clear, as well, is the idea according to which the rules presently in force are not sufficient to obtain the aimed result. Therefore, it is necessary to lay down some basic reforms, both at the national and at the supranational level (Varvello and Montaldo, 2017).

The invitation to the European legislator is formulated in very specific terms. Concerning its relationship with the Member States, "a Directive should be issued [...] to provide for the protection of the commons". As regards, instead, the European system itself, the draft states that the Commission should introduce "a new form of legitimate and democratic European Constitutional Law" and should "take all the necessary steps in order for the European Parliament [...] to be granted Constitutional Assembly Status in order to adopt a Constitution of the Commons".

The overall aim is to create "a correct balance between the public and the private sector". This means that, notwithstanding the background idea about the inherently dangerous privatisation phenomenon (Mattei, 2013, p. 366), there is a strong awareness among the authors of the Charter about the necessity of conciliating public and private legal categories. Such hope is gradually (even though slowly) being put in place, as the civil society has lately started a rich and deep dialogue with the EU institutions (especially with the European Parliament) in order to obtain further attention for the commons in supranational hard law. An example thereof is the first European Commons Assembly, held in Brussels in November 2016, with the main purpose of raising awareness in the European institutions (for information, see https://euroalter.com/2017/commons-political-force).

\subsection{The protection of the commons and beyond: the problem of justiciability}

Another open issue which clearly arises from the draft European Charter relates to the possibility for the populations, i.e. owners of the right of access to resources, of being protected in case of a breach. Of course, this issue is strictly connected with the physiognomy of each legal system and is partially a consequence of the legislative choices about the implementation of private and public ownership in the field of commons.

Nevertheless, the authors of the Charter decided to follow a rather extensive path. Thus, they provided for a general right of everybody to "always access the courts of law to protect the commons by mean of injunctive relief". This shows a strong will to give individuals immediately 'executive' legal positions, which may be efficiently protected by a judicial order addressed to an authority or to a private service provider. This instrument is flexible enough to be 
useful both when the commons are (material or non-material) goods and when they are services.

The implementation of these general tools, however, has the potential to produce important consequences in terms of identification of the subjects entitled to bring action. As the commons are seen as instruments to ensure a good quality of life to all people, each human being must be put in the condition to protect his or her subsequent rights. Taken to its maximum effect, this idea indiscriminately and uncontrollably enlarges the scope of possible stakeholders, which may occur parallel to the progressive extension of the concept of citizenship, which is a well-known phenomenon in many legal systems (Desforges et al., 2005, p. 439; Armstrong, 2006; Isin and Turner, 2007, p. 5; Joppke, 2007, p. 37; Lister, 2007, p. 49; Joppke, 1997, p. 6; Dahrendorf, 1974, p. 673). But, paradoxically, this view may be highly inefficient because of the lack of realistic awareness of the individuals about the true legal significance and implications of their rights. Therefore, the intervention by intermediate bodies, such as associations and local institutions - especially in cooperation with each other - could represent a good solution to produce an efficient system of justiciability.

\section{Ruling the Commons in a Dynamic Perspective: The Importance of Participation}

Nowadays, public authorities have the wide function to ensure the improvement of social welfare, compatibly with the rationalisation (and, possibly, a reduction) of spending. Thus, it is essential to indicate a series of goals that correspond to the satisfaction of basic general interests. Considering the commons in this dynamic view could bring a change in the idea of efficient and fair use of scarce resources, which does not require a deep revolution in the legal concepts connected with ownership and appropriation rules. In fact, shifting the attention from goods to substantial interests and their possible fulfilment gives administrative law a more incisive role. The main issue becomes the indication of a group of tools intended to enable an efficient management of the commons.

Therefore, it can be said that the 'guest of stone' in a legal discourse on the commons is greater concern for the mechanisms of involvement of the citizens. In such a view, when a resource may be strategic to ensure a good (or better) quality of life to the members of a community of users, these parties must be involved in the strategic decisions about the management and use of the commons. Acknowledging a new decisional role to the citizens may be a virtuous turning point towards a more efficient administrative action for a fair distribution of resources. It could also contribute to overriding the voices that, from different fields and points of view, express strong criticism about the frequent transfer of the tasks previously fully covered by administrative powers and competences from the public to the private sphere. The risk of 
undue prevalence of a logic of immediate economic gain is inherently linked with the growing implementation of managerial criteria to actions held in the public interest. A possible method to tackle this problem is to construct a new legal framework to protect the right of the populations to be involved not only in the use, but also in the management of the commons.

This solution is appropriate for two reasons. Primarily, it allows the emersion of minority needs and sensitiveness, which the institutions hardly even detect. Besides, a preliminary confrontation among the different groups of stakeholders reduces the risk of conflicts which, particularly in moments of crisis when the scarcity of resources is even more accentuated, is dangerously high (Heller, 1998, 622; Sabel and Zeitlin, 2008, 271; Sennett, 2011). The key (at least partially) is the broad conception of the democratic principle and the use of a dialogic approach to understand and solve problems. Thereby, it might also be possible to restore a harmonious relationship between private parties and public authorities, founded on good governance and ethical values. The Charter is, in my opinion, congruent with the direction indicated above. In addition, many open issues regard the time and method of involvement of the populations.

The problem is how to obtain their opinion. Moreover, the question is whether participation is desirable only to manage or also to select the commons. In fact, the importance of a resource or of a service may be perceived differently in different situations; hence, what is 'felt' as a fundamental need to be satisfied by a community might not be 'felt' as such somewhere else. The same is true (as already noticed) in the diachronic perspective. To address these doubts, a wise use of the inquiry model might be appropriate. In fact, inquiries are sometimes used in administrative law in order to involve in public decision-making also the citizens, who are to be the recipients - not individually, but as stakeholders, owners of a general or collective interest - of such decisions. This method allows the competent authority to obtain and connect information and opinions expressed during a dedicated procedure by the concerned groups of people. The inquiry model, therefore, is an evolution of the ancient 'right to be heard', but it is more complex than the acquisition of single participatory acts and requires, in order to work efficiently, a primary filter by the institutions (Simonati, 2014, p. 84). This may regard both the preliminary indication of groups of resources, among which the elements of the catalogue could be chosen, and the indication of specific stakeholders - representatives of specific wide-shared interests - whose intervention in the procedure is compulsory.

In the comprehensive architecture built by the Charter, another issue is how to measure the degree of efficiency of the management of the commons. Depending on the different legislative and institutional situations, many paths may be followed. As regards the 'property field', besides the 'classical' instrument of public ownership, different forms of collective domain may be used (Capone, 2016, p. 597; Borrini-Feyerabend, 2013; Eriksen, 1993; Hirsch and 
O'Hanlon, 1995; Nevola, 2011; Notaro and Paletto, 2011, p. 137; Pretty and Ward, 2001, p. 209; Stevenson, 1991). As regards the 'dynamic' forms of management, the implementation of local autonomies may be placed alongside the promotion of action by associations or other (at least, formally) private subjects.

The great heterogeneity of the concerned fields requires the choice of a common key, which may represent some kind of a passe-partout guarantee for democratic participation. This precious legal key may be indicated, in my opinion, in a wide use of the administrative procedure. Of course, in this specific field, the best practices which can be implemented are strongly influenced by the rules on administrative procedures in force in the various legal systems and there is no 'one fits all' solution. The next chapter presents some proposals with reference to the Italian legal system.

\section{A New Administrative Proceduralisation to Manage the Commons? Remarks with Reference to the Italian Experience}

Finally, some remarks may be expressed about the Italian legal system, which is relevant for various reasons. First, Italy is where the Charter was written, as the International University College has its institutional framework in the University of Turin. Second, in Italy the scientific debate on the commons among legal scholars is strong, especially as regards their systemic position 'between' private and public ownership. Moreover, the absence of specific rules on the commons at the national level has frequently driven the Italian local entities toward original experimentations. In the field of administrative action, such efforts must not neglect the applicable rules regarding administrative procedure, which compel the authorities to follow specific steps when issuing their decisions. From this point of view, indeed, the basic role of administrative procedure is commonly recognised in Italy.

Of course, simplification is a value for administrative action. Nonetheless - especially when many different public and private interests must be harmonised, such as in the field of management of the commons - the fragmentation into various steps of the exercise of power only apparently leads to complication, as in reality it ensures a more efficient participation by all the stakeholders. The Italian Constitutional Court's case law goes in the same direction. According to the Court, in fact, administrative procedures are the natural location for the fair involvement of all subjects and groups which aim at the protection of their respective interests (among others: Constitutional Court, 2 March 1962, No. 1; Constitutional Court, 21 March 1989, No. 143; Constitutional Court, 2 February 1990, No. 41; Constitutional Court, 29 April 1993, No. 204, Constitutional Court, 1 June 1995, No. 220; Constitutional Court, 3 June 1998, No. 211; Constitutional Court, 11 July 2000, No. 300; Constitutional Court, 2 May 2005, No. 172; Constitutional Court, 8 March 2006, No. 104). 
Actually, the fragmentation of the legal physiognomy of the commons prevents to consider the implementation of administrative procedure in the strict sense as the method to ensure their use in the public interest. In other words, the Italian law on administrative procedure (Law of 7 August 1990, No. 241 ) is not flexible enough to be suitable. In fact, it is based on participation of specific stakeholders in the procedure in which they have a direct interest. In the field of the management of the commons, however, the appropriative model is not clear and the indication of the subjects able to actively dialogue with the authorities is not simple. Therefore, more efficient participatory circuits, which allow gathering the contributions by groups of (public and private) stakeholders in a less formalised way, are needed. The main difficulty regards the involvement of all the members of the community of users, who in re ipsa are the holders of a participatory expectation.

Widespread participation is nowadays possible thanks to e-participatory instruments, but it would be utopian to believe that everyone is actually able to easily and freely access to the internet (Chadwick and May, 2003, p. 271). Therefore, the role of the public authorities - especially at the local level - as serious interlocutors and representatives of various groups of private stakeholders (and especially of the economically and socially weakest ones) must be re-established. Action by institutions can be fundamental also to grant a fair dialogue among different groups of stakeholders (for instance, the local populations and the private investors), who are often in opposite and rival positions as regards the exploitation of scarce resources (Hirshrnan, 1986).

This kind of cooperation among private subjects, groups and public bodies might give efficient answers to allow an effective empowerment of the populations, which are the main users of the resources, and simultaneously avoid factual and (so to say) 'self-managed' perceptions by each local group of inhabitants. In fact, too much fragmentation is dangerous as it is not governable, and a central coordination is necessary. Thus, the aim is to create (and enforce) collaborative networks among stakeholders, promote public-private partnerships, and involve citizens in strategic decisions. To reach these goals, a strong consensus among the interested populations is necessary. As consensus seems to be the result of a diachronic gradualism, its creation may be fruitfully based - even if no rules of law impose it - on a succession of logical and chronological steps.

In Italy, an interesting example of efficient administrative procedure best practices even in absence of hard law imposing such is spatial strategic planning (Gioioso, 2006, p. 37; Cangelli, 2012, p. 123; Perulli, 2004). At the first step of the procedure, the leading authority involves public and private stakeholders which may normally participate in the procedure either individually or through mediation of their associations (Lecci, 2011, p. 103 and p. 134; Gastaldi, p. 22). Then, according to a strongly collegial method, all the involved subjects and groups collaborate in indicating the basic results to be obtained in the public interest. In this step, the importance of public communication 
is fundamental (Kunzmann, 2000, p. 259) and has a double function. First, it diffuses among the interested populations a correct knowledge of the discussed points before strategic planning reaches its final version. Second, it stimulates the involvement of the socially and legally 'weakest' citizens, who are assisted in the comprehension of technicalities. Finally, the head of the leading authority undersigns a formal agreement with the representatives of all public and private partners. The legal power of the agreement is not clear, but it primarily aims at increasing the public opinion's attention for the planned projects. Normally, the strategic plan is also formally transferred into a public decision. After its formal emission, the implementation starts and is based on gradualism and flexibility of results, even if special bodies have the power (and the duty) to constantly monitor progress. This scheme, which in Italy is usually adopted as best practice (especially by several municipal-level authorities) (Simonati, 2015, p. 2404, where various practical examples are indicated), may be fruitfully applied also to implement democracy in the management of the commons.

\section{Short Conclusions}

The traditional legal conceptual background does not provide for efficient tools to describe and regulate the commons. Property law, in particular, is only partially useful because the basic point of the commons is not the kind of ownership, but how they are managed to maintain their public function. Therefore, the right perspective is perhaps to underline the potential importance of best practices of democratic participation of the directly involved populations in the procedures, followed by the administrative bodies to take the basic choices.

Another important issue regards the introduction of a new concept of administrative procedure, different from the one codified in general national laws. In fact, the traditional administrative procedure is normally aimed at issuing an individual final measure, the recipient of which is a single subject. The subject of the 'new' proceduralisation here proposed, instead, are the administrative decisions on the management of the commons: they have general content and their recipient is a group of people as a whole. This is, of course, an important difference which determines the specific needs of the pertinent procedure. In particular, it should be more flexible than the traditional one, but should be based on the same principles of pursuit of the public interest, fairness, impartiality, transparency, and participation by the interested parties. The necessary respect for such fundamental principles, even in absence of detailed rules on such procedures, provides a fundamental benchmark for all the practical implementations and experimentations, ensuring greater uniformity also among European countries.

These suggestions are coherent with the content of the draft European Charter, which was the starting point of the analysis conducted in the paper. As 
regards other issues, I cannot totally share the approach adopted. In particular, delegating all the strategic choices fully to the citizens (as it seems to be the aim of the document) may be too expensive in institutional terms. On the contrary, a gradual codification of participatory best practices, which have already been experimented - especially at the local level - to involve citizens in administrative decisions, might be a good idea. This would also allow postponing the 'revolutionary' stances about established legal tools, such as ownership and administrative procedure in the strict sense. Finally, from the point of view of the desirable legislative reforms, setting out merely principle rules would leave the institutions a chance to express their role, through a careful adaptation of the participatory mechanisms, in the light of the characteristics of an individual context. 


\section{References}

Anderson, J. (ed.) (2002). Transnational Democracy. Political spaces and border crossings, London-New York, Routledge.

Armstrong, C. (2006). Rethinking Equality. The Challenge of Equal Citizenship, Manchester, Manchester University Press.

Atkinson, A.B. (2008). The Changing Distribution of Earnings in OECD Countries, Oxford, Oxford University Press.

Azman, K.D. (2011). The Problem of "Democratic Deficit" in the European Union: International Journal of Humanities and Social Sciences, 1(5), pp. 242-250.

Barnes, P. (2006). Capitalism 3.0: A Guide to Reclaiming the Commons, San Francisco, Berrett-Koehler Publishers Inc.

Bell, J. (1992). Convergences and Divergences in European Administrative Law: Rivista Italiana Diriritto Pubblico Comunitario, 2(1), pp. 3-22.

Bennett, A. (ed.) (1997), How does privatization work? Essays on privatization in honour of Professor V.V. Ramanadham, London-New York, Routledge.

Borch, C. and Kornberger, M. (eds) (2015). Urban commons. Rethinking the city, New York, Routledge.

Borrini-Feyerabend, G. (ed.) (2013). Governance of protected areas, Gland, IUCN.

Bortolotti, B. and Siniscalco, D. (2004). The challenges of privatization : an international analysis, Oxford, Oxford University Press.

Camerlengo, Q. (2016). La controversa nozione di bene comune (The controversial concept of common good): Diritto e società, 3, pp. 557-571.

Cangelli, F. (2012). Piani strategici e piani urbanistici. Metodi di governo del territorio a confronto, Turin, Giappichelli.

Capone, N. (2016). Del diritto d'uso civico e collettivo dei beni destinati al godimento dei diritti fondamentali (The right of civic and collective use of goods pertaining to the enjoyment of fundamental rights): Politica del diritto, 4, pp. 597-636.

Caputi Jambrenghi, M.T.P. (2017). Note minme su beni comuni e funzioni amministrative (Minimal notes on common goods and administrative functions): Costituzionalismo.it. At <http://www.costituzionalismo.it/articoli/614/>, accessed 3 March 2018.

Cerilli Irelli, V. (2016). Beni comuni e diritti collettivi (The commons): Diritto e società, 3, pp. 529-534.

Chadwick, C. May (2003). Interaction between State and Citizens in the Age of the Internet: "e-Government" in the United States, Britain, and The European Union. Governance: An International Journal of Policy, Administration, and Institutions, 16(2), pp. 271-300.

Ciolli, I. (2016). Sulla natura giuridica dei beni comuni (On the Juridical nature of Commons): Diritto e società, 3, pp. 457-482.

Clarke, J. (2004). Dissolving the Public Realm? The Logics and Limits of Neo-liberalism. Journal of Social Policy, 33(1), pp. 27-48.

Council of Europe (ed.) (2011).Towards a Europe of Shared Social Responsibilities: Challenges and Strategies, Trends in Social Cohesion, Paris, Council of Europe Publishing, No. 23.

Crombez, C. (2003). The Democratic Deficit in the European Union. Much Ado about Nothing? European Union Politics, 4(1), pp. 101-120. 
Dahrendorf, R. (1974). Citizenship and Beyond: the Social Dynamics of an Idea. Social Research, 41(4), pp. 673-701.

D'Andrea, L. (2016). I beni comuni tra pubblico e privato (Commons between public and private). Diritto e società, 3, pp. 433-455.

Desforges, L., Jones, R. and Woods, M. (2005). New Geographies of Citizenship. Citizenship Studies, 9(5), pp. 439-451.

Eriksen, E.O. and Fossum, J.E. (eds) (2002). Democracy in the European Union. Integration through Deliberation? London-New York: Routledge.

Fedeli, V. and Gastaldi, F. (eds) (2004). Pratiche strategiche di pianificazione. Rflessioni a partire da nuovi spazi urbani in costruzione. Milan: Giuffrè.

Ferrarese, M.R. (2010). La governance fra politica e diritto. Bononia: Il Mulino.

Follesdal, A. and Hix, S. (2006). Why There is a Democratic Deficit in the UE: a Response to Majone and Moravcsik. Journal of Common Market Studies, 44 (3), pp. 533-562.

Freedland, M. and Auby J.B. (eds) (2006). The Public Law/ Private Law Divide: Une Attente Assez Cordiale?, Oxford, Hart Publishing.

Frydman, R. and Rapaczynski, A. (1994). Privatization in Eastern Europe: Is the State Withering away? Budapest: Central European university.

Gibson, D.E. (1993). Post-Industrialism: Prosperity or Decline? Sociological Focus, 26(2), pp. 147-163.

Giddens, A. (1991). The consequence of modernity. Stanford: Stanford University Press.

Gioioso, G. (2006). La pianificazione strategica partecipata in Italia. Rome: Formez.

Glyn, A. (2007). Capitalism Unieashed. Finance, Globalization and Welfare. Oxford: Oxford University Press.

Grazzini, E. (2012). Beni comuni e diritti di proprietà. Per una critica della concezione giuridica: MicroMega online. At <http://temi.repubblica.it/micromegaonline/beni-comuni-e-diritti-di-proprieta-per-una-critica-della-concezione-giur idica/?printpage=undefined\&refresh_ce>, accessed 3 March 2018.

Grazzini, E. (2011). Il bene di tutti. L'economia della condivisione per uscire dalla crisi. Rome: Editori Internazionali Riuniti.

Hardin, G. (1968). The Tragedy of the Commons. Science, 162(3859), pp. 12431248.

Haller, M. (1998). Private, Public and Common Ownership: Analyse and Kritik, 20(2), pp. 166-183.

Heller, M.A. (1998). The Tragedy of the Anticommons, Property in the Transition from Marx to Markets. Harvard Law Review, 111, pp. 621-688.

Hirsch, E. and O'Hanlon M. (eds.) (1995). The Anthropology of Landscape. Perspectives on Place and Space. Oxford: Clarendon Press.

Hirshrnan, A.O. (1986). Rival Views of Market Society and Other Recent Essays, New York: Elizabeth Sifton Books.

Hopkins, N. (ed.) (2013). Modern Studies in Property Law. Oxford: Hart Publishing.

Isin, E.F. and Turner, B. (2007). Investigating Citizenship: An Agenda for Citizenship Studies. Citizenship Studies, 11(1), pp. 5-17.

Joppke, C. (2007). Transformation of Citizenship: Status, Rights, Identity. Citizenship Studies, 11(1), pp. 37-48. 
Lange, D. (1981). Recognizing the Public Domain: Law \& Contemporary Problems, 44, pp. 147-178.

Lecci, P. (2011). Metodi e strumenti di governance territoriale. Il piano strategico negli enti locali. Rome: Aracne.

Leijonhufvud, A. (2009). Out of the Corridor: Keynes and the Crisis. Cambridge Journal of Economics, 33(4), pp. 741-757.

Leyronas, S. and Bambridge T. (2018). Commons and development. A renewed approach to addressing global challenges. Revue Internationale des Etudes du Développement, 233, pp. 11-29.

Levet, J.-L. (ed.) (2012). Reindustrialisation, j"écris ton nom. Paris: Fondation Jean Jaurès.

Lister, R. (2007). Inclusive Citizenship: Realizing the Potential. Citizenship Studies, 11(1), pp. 49-61.

Lister, R. (1997). Dialectics of Citizenship. Hypatia, 12(4), pp. 6-26.

Marella, M.R. (ed.) (2012). Oltre il pubblico e il privato. Per un diritto dei beni comuni. Verona: Ombre Corte.

Martinez Lopez, M.A. and Cattaneo, C. (eds) (2014). The squatters' movement in Europe: commons and autonomy as alternatives to capitalism. London: Pluto Press.

Mattei, U. (2013). Protecting the Commons: Water, Culture, and Nature: The Commons Movement in the Italian Struggle against Neoliberal Governance. South Atlantic Quarterly, 112(2), pp. 366-376.

Mattei, U. (2011). Beni comuni. Un manifesto. Rome: Laterza.

Mejstrik, M., Derviz, A., and Zemplin A. (eds) (1997). The privatization process in East-Central Europe: evolutionary process of Czech privatization. Dordrecht: Kluwer Academic.

Mishori, D. (2014). Reclaiming Commons Rights: Resources, Public Ownership and the Rights of Future Generations. Law \& Ethics of Human Rights, 8 (2), pp. 335-366.

Moravsik, A. (2004). Is There a "Democratic Deficite in World Politics? A Framework for Analysis. Government and Opposition, 39(2), pp. 336-363.

Nevola, G. (2011). Politics, Identity, territory. The "Strenght" and "Value" of nation-State, the Weakness of Regional Challenge. Trento: Università degli Studi di Trento, Quaderni del Dipartimento di Sociologia e Ricerca Sociale.

Notaro, S. and Paletto, A. (2011). Links between Mountain Communities and Environmental Services in the Italian Alps. Sociologia Ruralis, 51 (2), pp. 137-157.

Nussbaum, M.C. (2010). Not for Profit. Why Democracy Needs the Humanities. Princeton: Princeton University Press.

Ostrom, E., Burger, J., Field, C. B., Norgaard, R. B. and Policansky D. (1999), Revisiting the Commons: Local Lessons, Global Challenges. Science, 284(5412), pp. 278-282.

Ostrom, E. (1988). Governing the commons. Cambrige: Cambrige University Press.

Ostrom, E. and Hess, C. (eds.) (2007). Understanding Knowledge as a Commons. From Theory to Practice, Boston, Cambridge, Mass.: MIT Press.

Ostrom, E., Gardner, R. and Walker J. (1994). Games, and Common-Pool Resources. Ann Arbor: University of Michigan Press.

Pennacchi, L. (2012). Filosofia dei beni comuni. Crisi e primato della sfera pubblica. Rome: Donzelli. 
Perulli, P. (2004). Piani strategici: governare le città europee. Milan: Giuffrè.

Pevenhouse, J.C. (2002). Democracy. From the Outside-In? International Organizations and Democratization. International Organization, 56(3), pp. 515-549.

Pretty, J. and Ward, H. (2001). Social Capital and the Environment. World Development, 29(2), pp. 209-227.

Ramanadham, V.V. (ed.) (1993). Constraints and impacts of privatization. New York, London: Routledge \& Kegan Paul.

Ruffert, M. (ed.) (2009). The Public-Private Law Divide: Potential for Transformation? London: BIICL.

Sabel, C. and Zeitlin, J. (2008). Learning from Difference: The New Architecture of Experimentalist Governance in the EU. European Law Journal, 14(3), pp. 271-327.

Salet, W. and Faludi A. (eds) (2000). Revival of Strategic Spatial Planning. Amsterda: Royal Netherlands Academy of Arts and Sciences.

Samuelson, P. (2006). Enriching Discourse on Public Domain. Berkeley: Berkeley Center for Law and Technology, No. 23.

Scharf, G. (2002). Critical evaluation of the strategies of privatization and public offerings: Illustrated by examples of Deutsche Telekom. Hamburg: Diplomatica.

Sennett, R. (2011). Together: The Rituals, Pleasures and Politics of Cooperation. London, New York: Allen Lane (Penguin Books).

Simonati, A. (2015). Strategic spatial planning in Italy: a new model for two-way trust in administrative action. Foro amministrativo, 9, pp. 2403-2416.

Simonati, A. (2014). The Inquiry Model in Urban Planning: A Strategic Tool for Efficiency of Administrative Action? Italian journal of public law, 1, pp. 84-107.

Sirgiovanni, B. (2017). Dal diritto sui beni comuni al diritto ai beni comuni (From the right on the commons to the right to the commons). Rassegna di diritto civile, 1, pp. 229-246.

Staiano, S. (2016). "Beni comuni" categoria ideologicamente estenuata ("Commons" as a worn out ideological concept). Diritto e società, 3, pp. 415-432.

Stein, E. (2001). International Integration and Democracy: No Love at First Sight. The American Journal of International Law, 96(3), pp. 489-534.

Stevenson, G. (1991). Common property economics: a general theory and land use applications. Cambridge: Cambridge University Press.

Stiglitz, J. (1999). Knowledge as a Global Public Good. New York: Oxford University Press.

Varvello, F. and Montaldo S. (2017). Waiting for the rainy season: towards a democratic management of water commons under international and EU law: federalismi.it, 6. At <http://www.federalismi.it/ApplOpenFilePDF.cfm?artid $=33745 \&$ dpath $=$ document $\&$ dfile $=21032017161647$.pdf\&content=Towards +a+democratic+management+of+water+commons+under+international+an d+EU+law?+-+stato+-+dottrina+-+>, accessed 3 March 2018.

Viola, F. (2016). Bene comune e beni comuni (The common good and the commons). Diritto e società, 3, pp. 381-398. 